\title{
Spring Forage Selection by Tame Mule Deer on Big Sagebrush Range, British Columbia
}

\section{W. WILLMS AND A. McLEAN}

Highlight: A study was made on a spring range to determine forage selection by deer (Odocoileus hemionus hemionus) during a critical period in their nutritive status. The period from mid-February to the end of May was characterized by a diet changing from shrub to grass to shrub and forb. Generally, selection favoured the most recently produced grass and forb species. Of the grass species, Sandberg bluegrass (Poa sandbergii) constituted the most bites in the diet but bluebunch wheatgrass (Agropyron spicatum) was preferred. Considerable variation occurred in the diets among the deer. One deer preferred shrubs while the other two preferred grass.

Seasonal diets of both mule deer and cattle have been studied in southern British Columbia in order to evaluate potential competition for forages (Willms et al. 1976; McLean and Willms 1977). The studies were based on rumen samples. The samples for deer were obtained from dead animals, thus the diet represented individual

\footnotetext{
The authors are graduate student, Department of Plant Science, University of Alberta, Edmonton, and research scientist (Range Ecology), Agriculture Canada Research Station, Kamloops, B.C., V2B

The study is Contribution no. 269.

Manuscript received August 11, 1977
} 8 A9 preferences of many animals. This resulted in considerable variation in the estimate of each plant group or "type" among samples. Despite the variation, the deer showed marked selection for non-grasslike plants during most of the study period from fall to early spring. Considerable deviation occurred in early spring from mid-March to midApril when consumption of grass was high. Cattle, on the other hand, preferred grass throughout the year.

Grass provides the first new-growth forage for deer following a winter diet of shrubs and forbs, which was high in fiber and low in crude protein (unpublished data). Grass is very palatable in spring being high in crude protein and low in crude fiber and only big sagebrush (Artemisia tridentata) has digestibility near that of bluebunch wheatgrass (Hickman 1975). However, microbial activity and consequently digestion may be inhibited by the essential oils present in big sagebrush (Nagy and Tengerdy 1968; Oh et al. 1967).

In earlier studies by Willms et al. (1976) and McLean and Willms (1977), grass became available to deer in midMarch, or earlier when fall regrowth was present. The time of availability corresponded approximately to the 130th day of gestation for deer. This is prior to rapid fetal development and may be instrumental in conditioning the doe for that phase and the later period of lactation. 
Early availability of spring growth is likely more important to juvenile deer than it is to adults. The energy required for basal metabolism is based on weight with an exponent that is less than 1 (Moen 1975). Therefore, the small body will have greater energy demands for basal metabolism than the large body and food conversion to body tissue will be less efficient. In this situation, the benefits accrued from good quality food clearly favour the small animal.

Since the diets of both deer and cattle consist mainly of grass in spring, it is important to know the species utilized to understand competition. Furthermore, since different grass species do not initiate growth and mature at the same rate, chemical differences will occur. Animals, therefore, may alter their selection during the growing and maturing period of grass. This paper reports on a study to investigate: (1) the forage selection by mule deer from mid-February to the end of May; (2) the use made of several grass - species during that period; and (3) the variation in species selection among mule deer.

The study was conducted on range located about $24 \mathrm{~km}$ northwest of Kamloops, British Columbia. The range is in the big sagebrush-bluebunch wheatgrass vegetation zone described by McLean (1970). Forage selection was studied in two habitats, namely, a flat field seeded to crested wheatgrass (Agropyron cristatum) and a knoll with a vegetative cover of needleandthread (Stipa comata), Sandberg bluegrass, and bluebunch wheatgrass. Big sagebrush was the dominant shrub in each habitat. The two sites were located adjacent to one another ranging in elevation from 650 to $750 \mathrm{~m}$. The flat field habitat was used by cattle in preference to the knoll (McLean and Willms 1977). Deer, on the other hand, preferred the knoll.

\section{Methods}

\section{Selection Trials}

The study was made using three tame, harness-broken deer consisting of two castrated adult bucks and one adult doe. The animals were enclosed in a pen adjacent to the study site and fed a pelleted ration, described by Wood et al. (1961), and browse ad lib. During the first half of the study period, the browse consisted of Douglasfir (Pseudotsuga menziessi) branches and in the second half of mountain maple (Acer douglasii), aspen (Populus tremuloides), and Saska- toon serviceberry (Amelanchier alnifolia) branches. The browse species were fed to supplement an artificial diet and to provide the tame deer with forage also available to the free ranging deer using communities similar to those on the study area. Feeding a concentrate to tame deer does not appear to affect their forage selection (Regelin et al. 1976). The deer were trained and handled during the study in a similar manner as described by Reichert (1972). The deer were kept in a shoulder harness with leash and allowed unrestricted movement within the two habitats. Each observation terminated when the deer either stopped feeding or left the study area. The area covered by the feeding animal provided access to all major types of forage. Diets were determined by counting the bites taken from each plant species. A bite was counted each time forage was removed from the plant. Wallmo et al. (1972) found that the difference in the species composition estimates of the diet were negligible when the bite samples were related to the dry weight of forage. This does not mean that differences in the bite size among species does not exist but that large variation within a species reduces the importance of differences among them. For this reason, the bite sample may be a better indicator of forage preference then it is of diet. Observations were made biweekly for each deer in both habitats. For analytical purposes, those observations with less than 20 bites were discarded.

\section{Statistical Analysis}

Eighty-nine usable observations were made, with an averae of 225 bites per observation, during the period from February 14 to May 31. For analysis of variance, the period was divided into four sub-periods, namely: February 14 to March 5(1); March 6 to April 4(2); April 5 to May 5 (3); and May 6 to May 31 (4). Portioning the period into four subperiods was done on the basis of the growth and development of herbaceous forage. Simple analysis of variance was made with data normalized with the arcsine, square root transformation. Tests were made to determine significant differences by deer in the selection of plant types and species, among animals and periods, and between habitats. Differences between means were determined by Duncan's multiple range test.

Regression analyses were made to describe the selection of both plant types and individual species over time for the entire period. Regression analysis was made for each plant type and for those grass and shrub species that showed consistent use during the period. Regression equations were calculated for the three deer combined as well as for two groups of one and two deer for the observations from the knoll habitat only. This was made to eliminate variation between animals that appeared to select different types of forage and to permit a more accurate description of the effect of time on forage selection. The data were tested for significance to the three degree polynominal as described by Goulden (1952). The additional sum of squares accounted for by each degree was tested against the residual sums of squares with the $F$-test.

The foliage cover of major grass and shrubs species was estimated in each habitat from 20 or $221-\mathrm{m}^{2}$ plot. Clusters of two plots were located at randomly located sites. The average cover, with 95\% confidence limits, and frequency of occurrence were calculated for each species. Forage weight, which is correlated to cover (Payne 1974), varies through the growing season. Regression equations predicting the relative availability of each forage species were constructed from data obtained from clipped plots for periods in mid-April and midMay.

\section{Results}

Grass was the dominant constituent in the diet of the deer on both open range habitats during sub-periods 2, 3, nd 4 (Table 1). The species contributing most forage was Sandberg bluegrass. Crested wheatgrass and bluebunch wheatgrass were both frequently used in the flat field, and the latter species also on the knoll habitat. Grass use peaked in April from almost no use in February (Fig. 1).

Most forb utilization did not occur until May, at which time numerous species contributed to the diet. Frequently selected species in the flat field were alfalfa (Medicago sativa), dandelion (Taraxacum officinale), and yarrow (Achillea millefolium). On the knoll area the most frequently selected species were purple avens (Geum triflorum), fleabane (Erigeron ssp.), and pussytoes (Antennaria ssp.) (Table 1).

Shrub use was inversely proportional to grass use from February to May (Fig. 1). With a higher use of forbs and grass in May, however, shrub use was correspondingly less than in February. Shrub species utilized consisted almost entirely of pasture sage (Artemisia frigida) and big sagebrush (Table 1).

Grasses, forbs, and shrubs were selected differently among sub-periods (Table 1). Polynominal regressions, shown in Figure 1, generalize 
Table 1. Percent bites of important species and percent frequency of occurrence in the diets of three deer in 1974 on two habitats and four sub-periods.

\begin{tabular}{|c|c|c|c|c|c|c|c|c|c|c|c|c|c|c|c|c|}
\hline \multirow[t]{5}{*}{ Species } & \multicolumn{8}{|c|}{ Flat field habitat } & \multicolumn{8}{|c|}{ Knoll habitat } \\
\hline & \multicolumn{8}{|c|}{ Sub-period } & \multicolumn{8}{|c|}{ Sub-period } \\
\hline & \multicolumn{2}{|l|}{1} & \multicolumn{2}{|l|}{2} & \multicolumn{2}{|l|}{3} & \multicolumn{2}{|l|}{4} & \multicolumn{2}{|l|}{1} & \multicolumn{2}{|l|}{2} & \multicolumn{2}{|l|}{3} & \multicolumn{2}{|l|}{4} \\
\hline & \multicolumn{2}{|c|}{14 Feb - 5 Mar } & \multicolumn{2}{|c|}{$6 \mathrm{Mar}-4 \mathrm{Apr}$} & \multicolumn{2}{|c|}{5 Apr - 5 May } & \multicolumn{2}{|c|}{6 May - 31 May } & \multicolumn{2}{|c|}{$14 \mathrm{Feb}-5 \mathrm{Mar}$} & \multicolumn{2}{|c|}{$6 \mathrm{Mar}-4 \mathrm{Apr}$} & \multicolumn{2}{|c|}{5 Apr - 5 May } & \multicolumn{2}{|c|}{6 May - 31 May } \\
\hline & $\overline{\mathbf{x}} \pm \mathrm{SE}$ & $\% \mathrm{f}$ & $\overline{\mathrm{x}} \pm \mathrm{SE}$ & $\% \mathrm{f}$ & $\overline{\mathrm{x}} \pm \mathrm{SE}$ & $\% \mathrm{f}$ & $\overline{\mathrm{x}} \pm \mathrm{SE}$ & $\% \mathrm{f}$ & $\overline{\mathrm{x}} \pm \mathrm{SE}$ & $\% \mathrm{f}$ & $\overline{\mathrm{x}} \pm \mathrm{SE}$ & $\% \mathrm{f}$ & $\bar{x} \pm S E$ & $\% \mathrm{f}$ & $\overline{\mathrm{x}} \pm \mathrm{SE}$ & $\% \mathrm{f}$ \\
\hline Grass & & & & & & & & & & & & & & & & \\
\hline Agropyron cristatum & $1.0 \pm 1.0$ & 20 & $27.6 \pm 10.6$ & 75 & $17.6 \pm 8.1$ & 88 & $28.0-9.3$ & 92 & 0 & 0 & 0 & 0 & 0 & 0 & 0 & 0 \\
\hline Agropyron spicatum & $0^{a}$ & 0 & $14.8 \pm 5.9^{a}$ & 58 & $14.2 \pm 6.7^{\mathrm{a}}$ & 62 & $6.4 \pm 2.4$ & 58 & $5.7 \pm 5.7^{b}$ & 12 & $5.5 \pm 1.6^{\mathrm{b}}$ & 53 & $16.5 \pm 5.2^{\mathrm{a}}$ & 100 & $10.2 \pm 2.8^{a b}$ & 55 \\
\hline Bromus tectorum & 0 & 0 & $1.7 \pm 1.1$ & 42 & $0.5 \pm 0.5$ & 12 & $5.7 \pm 3.0$ & 42 & 0 & 0 & $0.6 \pm 0.6$ & 20 & $2.0 \pm 0.1$ & 67 & $8.4 \pm 2.4$ & 71 \\
\hline Koeleria cristata & 0 & 0 & 0 & 0 & $14.7 \pm 5.7$ & 75 & $4.3 \pm 2.4$ & 33 & $0.8 \pm 0.8$ & 12 & $1.6 \pm 0.9$ & 27 & $9.6 \pm 7.2$ & 33 & $6.3 \pm 2.0$ & 76 \\
\hline Poa sandbergii & $15.2 \pm 12.5^{\mathrm{ab}}$ & $b_{40} 40$ & $41.8 \pm 11.0^{\mathrm{a}}$ & 75 & $38.4 \pm 13.1^{\mathrm{a}}$ & 62 & $1.4 \pm 1.0^{b}$ & 25 & $14.1 \pm 8.1^{b}$ & 62 & $57.1 \pm 8.8^{\mathrm{a}}$ & 93 & $52.6 \pm 6.4^{\mathrm{a}}$ & 100 & $2.0 \pm 0.8^{b}$ & 41 \\
\hline Stipa spp. & 0 & 0 & 0 & 0 & $0.1 \pm 0.1$ & 12 & $0.6 \pm 0.6$ & 8 & $1.6 \pm 1.6$ & 12 & $0.3 \pm 0.3$ & 7 & $0.6 \pm 0.4$ & 33 & $0.3 \pm 0.3$ & 7 \\
\hline Other & 0 & & & & 2.8 & & 4.7 & & 1.8 & & 0.3 & & 4.6 & & 9.1 & \\
\hline Total & $16.2^{\mathrm{c}}$ & & $85.9^{\mathrm{a}}$ & & $98.6^{\mathrm{a}}$ & & $51.1^{\mathrm{b}}$ & & $24.0^{\mathrm{b}}$ & & $65.4^{\mathrm{a}}$ & & $85.9^{\mathrm{a}}$ & & $35.3^{\mathrm{b}}$ & \\
\hline Forbs & & & & & & & & & & & & & & & & \\
\hline Antennaria spp. & 0 & 0 & $0.1 \pm 0.04$ & 17 & $0.4 \pm 0.3$ & 25 & $0.2 \pm 0.2$ & 8 & 0 & 0 & $0.3 \pm 0.1$ & 27 & $1.1 \pm 0.6$ & 58 & $4.1 \pm 1.5$ & 59 \\
\hline Achillea millefolium & $0.4 \pm 0.4$ & 20 & $0.1 \pm 0.1$ & 8 & $0.1 \pm 0.4$ & 25 & $4.2 \pm 2.5$ & 67 & 0 & 0 & $0.8 \pm 0.4$ & 27 & $1.7 \pm 0.8$ & 50 & $1.5 \pm 0.5$ & 47 \\
\hline Calochortus macrocarpus & 0 & 0 & 0 & 0 & 0 & 0 & $0.1 \pm 0.1$ & 8 & 0 & 0 & 0 & 0 & $0.1 \pm 0.1$ & 42 & $0.1 \pm 0.1$ & 12 \\
\hline Erigeron spp. & $2.7 \pm 2.7$ & 20 & 0 & 0 & 0 & 0 & 0 & 0 & 0 & 0 & $0.6 \pm 0.4$ & 25 & $0.4 \pm 0.3$ & 17 & $5.5 \pm 1.6$ & 80 \\
\hline Fritillaria pudica & 0 & 0 & $0.1 \pm 0.1$ & 8 & $0.1 \pm 0.1$ & 12 & 0 & 0 & 0 & 0 & 0 & 0 & $0.5 \pm 0.4$ & 25 & 0 & 0 \\
\hline Geum triflorum & 0 & 0 & 0 & 0 & $0.3 \pm 0.3$ & 12 & $0.5 \pm 0.5$ & 8 & 0 & 0 & 0 & 0 & $1.9 \pm 1.3$ & 25 & $18.3 \pm 3.9$ & 82 \\
\hline Lomatium macrocarpum & 0 & 0 & 0 & 0 & 0 & 0 & $0.4 \pm 0.4$ & 8 & 0 & 0 & 0 & 0 & $0.1 \pm 0.1$ & 25 & $0.9 \pm 0.4$ & $4 !$ \\
\hline Medicago sativa & 0 & 0 & 0 & 0 & 0 & 0 & $17.2 \pm 8.1$ & 12 & 0 & 0 & 0 & 0 & $0.4 \pm 0.4$ & 8 & $6.3 \pm 3.0$ & 35 . \\
\hline Tragopogon pratensis & 0 & 0 & 0 & 0 & $0.2 \pm 0.2$ & 12 & $3.1 \pm 1.3$ & 50 & $2.5 \pm 1.0$ & 62 & $0.8 \pm 0.3$ & 40 & $0.4 \pm 0.2$ & 3.3 & $1.2 \pm 1.0$ & 35 \\
\hline Other & 0 & & 1.2 & & 0.1 & & 4.0 & & 1.3 & & 0.1 & & 1.4 & & 0 & \\
\hline Total & $3.1^{b}$ & & $1.5^{\mathrm{b}}$ & & $1.2^{\mathrm{b}}$ & & $42.5^{\mathrm{a}}$ & & $3.8^{\mathrm{b}}$ & & $2.6^{\mathrm{b}}$ & & $8.5^{\mathrm{b}}$ & & $44.0^{\mathrm{a}}$ & \\
\hline Shrubs & & & & & & & & & & & & & & & & \\
\hline Artemisia frigida & $24.8 \pm 14.3^{\mathrm{a}}$ & 60 & $2.8 \pm 1.5^{b}$ & 58 & $0.1 \pm 0.1^{b}$ & 25 & $2.9 \pm 2.1^{b}$ & 42 & $25.1 \pm 9.2^{\mathrm{a}}$ & 100 & $15.6 \pm 4.9^{\mathrm{a}}$ & 87 & $4.1 \pm 1.7^{\mathrm{a}}$ & 100 & $11.5 \pm 3.8^{\mathrm{a}}$ & 88 \\
\hline Artemisia tridentata & $36.7 \pm 17.4^{\mathrm{a}}$ & 80 & $8.2 \pm 7.7^{b}$ & 42 & $0.1 \pm 0.04^{b}$ & 25 & $2.4 \pm 1.7^{b}$ & 33 & $12.5 \pm 2.9^{\mathrm{a}}$ & 100 & $11.9 \pm 6.1^{\mathrm{a}}$ & 93 & $1.4 \pm 0.6^{\mathrm{b}}$ & 66 & $2.2 \pm 0.8^{\mathrm{b}}$ & 47 \\
\hline Chrysothamnus nauseosus & $1.1 \pm 0.6$ & 40 & $1.2 \pm 1.2$ & 8 & 0 & 0 & 0 & 0 & $0.8 \pm 0.8$ & 12 & $2.0 \pm 0.9$ & 47 & 0 & 0 & $0.2 \pm 0.2$ & 18 \\
\hline Rosa spp. & 0 & 0 & 0 & 0 & 0 & 0 & $0.9 \pm 0.9$ & 8 & $8.2 \pm 7.2$ & 25 & $0.7 \pm 0.5$ & 20 & $0.1 \pm 0.1$ & 8 & $6.4 \pm 1.9$ & 59 \\
\hline Other & 18.1 & & 0.2 & & 0 & & 0.2 & & 10.5 & & 0.5 & & 0 & & 0.4 & \\
\hline Total & $80.7^{\mathrm{a}}$ & & $12.4^{\mathrm{b}}$ & & $0.2^{b}$ & & $6.4^{\mathrm{b}}$ & & $57.1^{\mathrm{a}}$ & & $30.7^{b}$ & & $5.6^{\mathrm{c}}$ & & $20.7^{b c}$ & \\
\hline Moss & & & & & & & & & & & & & & & & \\
\hline Total & 0 & 0 & $0.2 \pm 0.2$ & 8 & 0 & 0 & 0 & 0 & $7.8 \pm 4.0$ & 62 & $1.0 \pm 0.5$ & 40 & 0 & 0 & 0 & 0 \\
\hline Trees & & & & & & & & & & & & & & & & \\
\hline Pinus ponderosa & 0 & 0 & 0 & 0 & 0 & 0 & 0 & 0 & $0.2 \pm 0.2$ & 12 & 0 & 0 & 0 & 0 & 0 & 0 \\
\hline Pseudotsuga mensiesii & 0 & 0 & 0 & 0 & 0 & 0 & 0 & 0 & 0 & 0 & $0.2 \pm 0.2$ & 20 & 0 & & 0 & 0 \\
\hline Other & 0 & & 0 & & 0 & & 0 & & 7.1 & & 0 & & 0 & & 0 & \\
\hline Total & 0 & 0 & 0 & 0 & 0 & 0 & 0 & 0 & $7.3 \pm 2.3$ & & $0.3 \pm 0.2$ & & 0 & & 0 & \\
\hline
\end{tabular}

a, b. c averages in a row (within each habitat) with the same superscript not significantly different at $P<0.05$.

the periodic trends of plant-type consumption during the period. The $R^{2}$ was less than 0.50 only for shrubs on the knoll habitat (Table 2).

Plant type selection difference $(P<0.05)$ among animals were evident only on the knoll area between deer 1 and deer 2 and 3 . In subperiod 2 , deer 1 selected $22 \%$ grass while deer 2 and 3 selected about $85 \%$ grass. In sub-period 4 , the proportion of grass selected by the two groups was 18 and $45 \%$. The difference of grass selection among animals was expressed by a reciprocal selection of shrubs. Forb selection did not differ among animals.

Selection differences $(P<0.01)$ of plant types occurred between habitats in sub-periods 3 and 4 . Grass contributed about $15 \%$ more to the diet on the flat field than it did on
Table 2. Polynomial equations describing the selection of three plant types and several plant species by three deer on the flat field and knoll habitats $(x=$ number of days from February 15 , $y=\%$ forage in diet).

\begin{tabular}{lllccc}
\hline Habitat & & \multicolumn{1}{c}{ Equation } & $\mathrm{R}^{2}$ & $\begin{array}{c}\text { Level of } \\
\text { significance }\end{array}$ \\
\hline Flat field & All grasses & $\mathrm{y}=-43.51+4.64 \times-0.038 \times 2$ & .65 & $*$ \\
& Poa sandbergii & $\mathrm{y}=8.24+1.30 \times-0.014 \times 2$ & .25 & $*$ \\
& All forbs & $\mathrm{y}=25.45-1.34 \times 0.016 \times 2$ & .64 & $*$ \\
& All shrubs & $\mathrm{y}=159.02-6.31 \times+0.080 \times 2-0.0003 \times 3$ & .75 & $*$ \\
& Artemisia tridentata & $\mathrm{y}=53.54-1.41 \times+0.009 \times 2$ & .27 & $*$ \\
& Artemisia frigida & $\mathrm{y}=38.79-1.08 \times+0.007 \times 2$ & .47 & $*$ \\
Knoll & All grasses & $\mathrm{y}=-3.49+2.92 \times-0.026 \times 2$ & .50 & $*$ \\
& Agropyron spicatum & $\mathrm{y}=-3.65+0.53 \times-0.004 \times 2$ & .10 & $*$ \\
& Poa sandbergii & $\mathrm{y}=-13.74+3.93 \times-0.063 \times 2+0.00025 \times 3$ & .50 & $*$ \\
& All forbs & $\mathrm{y}=6.52-0.45 \times+0.008 \times 2$ & .69 & $*$ \\
& All shrubs & $\mathrm{y}=74.89-1.77 \times+0.012 \times 2$ & .33 & $*$ \\
& Artemisia tridentata & $\mathrm{y}=14.39-0.14 \times$ & .09 & $*$ \\
& Artemisia frigida & $\mathrm{y}=32.42-0.67 \times+0.0045 \times 2$ & .13 & $\mathrm{NS}$ \\
& Chrysothamnus nauseosus & $\mathrm{y}=0.29+0.16 \times-0.004 \times 2+0.00002 \times 3$ & .16 & $*$ \\
\hline
\end{tabular}

NS Not significant at $P<0.05$

* Significant at $\mathrm{P}<0.05$ 
the knoll in sub-period 3 . In subperiod 3, the deer selected about $7 \%$ more forbs and $5.5 \%$ more shrubs on the knoll habitat than on the flat field habitat. Shrub selection was $14 \%$ greater on the knoll habitat in sub-period 4. Sandberg bluegrass and bluebunch wheatgrass were not selected significantly different $(P<$ 0.05 ) between habitats within any sub-period. Significant changes occurred, however, among sub-periods (Table 1, Fig. 1). The species contributing to most of the among-animal selection differences for the grass type was Sandberg bluegrass in sub-period 2 and bluebunch wheatgrass in sub-periods 3 and 4.

Selection of big sagebrush and pasture sage declined after sub-period 1 but increased slightly in subperiod 4 (Table 1, Fig. 1). Both species contributed to the withinanimal variation of shrub selection in sub-periods 2 and 4 . In sub-period 2 , deer 1 selected 32 and $34 \%$ big sagebrush and pasture sage, respectively, while the other two deer both selected 2 and $5 \%$ of these species. In sub-period 4, deer 1 selected $5 \%$ big sagebrush and $26 \%$ pasture sage while deer 2 and 3 selected $1 \%$ big sagebrush and $4 \%$ pasture sage. The species contributing to the shrub selection differences between habitats were big sagebrush in sub-period 3 and pasture sage in sub-periods 2 to 4 . Only $1 \%$ more big sagebrush was selected on the knoll habitat but 12,3 , and $9 \%$ more pasture sage was selected in sub-periods 2,3 , and 4 , respectively, from the same habitat.

The regressions in Table 3 represent data stratified by animals with similar diets. The unstratified data are shown in Table 2. For most regressions, the $R^{2}$ increased in the stratified data.

The cover of important grass and shrub species vaired between the knoll and flat field habitats (Table 4), although an inadequate sample size negated the significance for all except the Agropyron species. The frequency of occurrence for most species is greater than $50 \%$, suggesting ready accessibility. Noteworthy is the low frequency for bluebunch wheatgrass on the flat field. The estimates of weight were made from regressions with an average sample size of 20 and an $R^{2}$ ranging from .53 to .86 . The mid-April and mid-
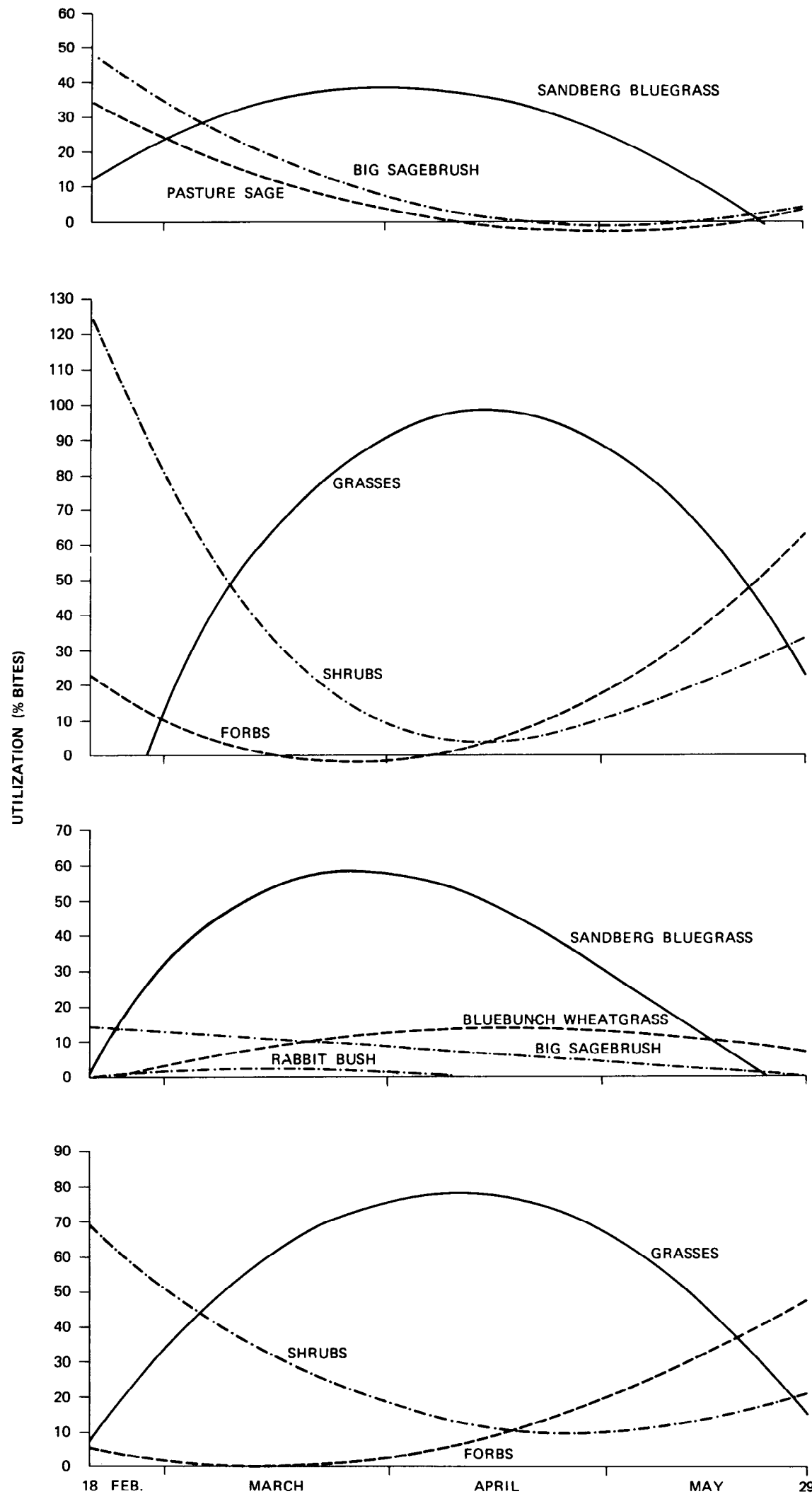

Fig. 1. (top to bottom) Polynomial regressions used to estimate utilization by three deer on the open field habitat of big sagebrush, pasture sage, and Sandberg bluegrass; also of grasses, forbs, and shrubs. Estimated utilization by three deer on the knoll habitat of big sagebrush. rabbitbrush, bluebunch wheatgrass; also of Sandherg hluegrass and grasses, forbs and shrubs.

May estimates of weight ( $\mathrm{gm}$ per $\mathrm{m}^{2}$ ) for the grass species on the flat field habitat were: Crested wheatgrass,
42.9 and 72.1 ; bluebunch wheatgrass 1.2 and 3.7; Sandberg bluegrass, 7.7 and 10.4; and needleandthread, 7.6 
Table 3. Polynomial equations describing the selection of three plant types and several plant species by two deer groups on the knoll habitat $(x=$ number of days from February 15 , $\mathbf{y}=\%$ in forage in diet.)

\begin{tabular}{lllcc}
\hline \hline $\begin{array}{l}\text { Plant type } \\
\text { or species }\end{array}$ & Deer & Equation & $\mathrm{R}^{2}$ & $\begin{array}{c}\text { Level of } \\
\text { significance }\end{array}$ \\
\hline All grasses & 1 & $\mathrm{y}=-10.20+2.39 \times-0.021 \times 2$ & .39 & $*$ \\
& 2,3 & $\mathrm{y}=-28.48+5.83 \times-0.085 \times 2+0.0003 \times 3$ & .79 & $*$ \\
Agropyron spicatum & 1 & $\mathrm{y}=-1.73+0.29 \times 0.0026 \times 2$ & .24 & $\mathrm{NS}$ \\
& 2,3 & $\mathrm{y}=-5.30+0.67 \times-0.005 \times 2$ & .12 & $\mathrm{NS}$ \\
Poa sandbergii & 1 & $\mathrm{y}=-3.46+1.18 \times-0.011 \times 2$ & .27 & $*$ \\
& 2,3 & $\mathrm{y}=-35.32+6.24 \times-0.105 \times 2+0.00046 \times{ }^{3}$ & .74 & $*$ \\
All forbs & 1 & $\mathrm{y}=12.69-0.70 \times+0.010 \times 2$ & .63 & $*$ \\
& 2,3 & $\mathrm{y}=10.54-1.06 \times+0.024 \times 2-0.0001 \times 3$ & .75 & $\mathrm{NS}$ \\
All shrubs & 1 & $\mathrm{y}=69.41-0.21 \times-0.0004 \times 3$ & .45 & $*$ \\
& 2,3 & $\mathrm{y}=103.26-4.06 \times+0.050 \times 2-0.0002 \times 3$ & .88 & $*$ \\
Artemisia tridentata & 1 & $\mathrm{y}=5.28+2.03 \times-0.046 \times 2+0.00025 \times 3$ & .28 & $\mathrm{NS}$ \\
\multirow{3}{*}{ Artemisia frigida } & 2,3 & $\mathrm{y}=16.67-0.45 \times+0.003 \times 2$ & .53 & $*$ \\
& 1 & $\mathrm{y}=7.38+2.12 \times 0.050 \times 2+0.0003 \times 3$ & .24 & $\mathrm{NS}$ \\
Chrysothamnus nauseosus & 2,3 & $\mathrm{y}=42.76-1.18 \times+0.008 \times 2$ & .49 & $*$ \\
& 1 & $\mathrm{y}=-0.18+0.13 \times-0.003 \times 2+0.00001 \times 3$ & .22 & $\mathrm{NS}$ \\
\hline
\end{tabular}

NS Not significant at $P<0.05$

* Significant at $\mathrm{P}<0.05$ and 19.2. The estimates on the knoll habitat were: bluebunch wheatgrass, 3.8 and 10.1; Sandberg bluegrass, 7.1 and 9.7 ; and needleandthread, 12.4 and 32.1 .

\section{Discussion}

The seasonal utilization of plant types by three tame deer were similar to those reported by Willms and McLean (1976) for free-ranging animals on similar range. Although direct comparison are difficult because sub-periods do not coincide in dates and duration, the proportion of grasses and forbs in the diets were generally greater than those determined for wild deer. The difference was due to the presence of Douglasfir in the diet of free-ranging animals. This constitutes the tree type not available to the tame animals on the open range habitats.

Two factors affecting food selection could be distinguished in this study. They are food availability and preference. Both factors are dynamic through time and vary with habitat and individual animals. The result is a well-defined seasonal trend of forage consumption (for both plant types and species) with periodic variation that can be removed by data stratification into individual animals and habitats.

For this study, availability is defined in terms of percent cover and percent frequency of occurrence. Although these estimates do not predict biomass accurately, they predict the search effort required to locate the forage. Since percent cover is essentially a constant variable for perennial grasses through the growing season, a more accurate estimate is obtained by converting to a weight basis for specific periods. Weight estimates prior to April would likely show only Sandberg bluegrass to be available because growth of other grasses would have been insufficient to permit utilization.

\section{Grass Selection}

On the basis of the availability and selection data (Tables 4 and 1 respectively) it appears that Sandberg bluegrass and bluebunch wheatgrass were both highly preferred. Crested wheatgrass and Junegrass rated slightly lower. Needleandthread was considerably less preferred than any other grass species.

The above rating is general and may vary from one period to another. Phenological progression is not synchronized. Hence the availability of green forage is not predicted with the same accuracy for each period. Also, palatability differences among species are affected by stage of maturity. A combination of these factors ensures an early high preference but a late season low preference for Sandberg bluegrass. Needleandthread is a late spring growing species and does not produce sufficient green foliage for grazing in the first two sub-periods.

Differences in springtime foliage palatability not only affect species selection but also differential selection of plants with a species. For instance, observations by the authors suggest that palatability may differ between plants of two geographic sites with distinct micro-climatic conditions. In this case, palatability differences may be the result of climate-altered rates of plant maturation or adaphic-altered rates of nutrient availability. On the other hand, plant selection may be affected by the presence of unpalatable mature foliage within a plant creating a barrier effect. This effect occurs with bunchgrass. All other grass species referred to in this paper are grasses without persistent stalks. In this study, foliage from bluebunch wheatgrass and crested wheatgrass was utilized only from plants where the mature stalks had been removed prior to spring growth. The most common method for removing stalks is with fall grazing by cattle. Presumably the heights to which the stalks are removed in the fall will determine the time when spring growth becomes available to deer.

Large data variation negated the significance of mean utilization differences of each plant type between habitats. Generally, however, grass use was greater in the flat field largely as a result of crested wheatgrass consumption. The difference
Table 4. Ground cover and percent frequency of several major perennial grass species and shrub species in the flat field and knoll habitats.

\begin{tabular}{|c|c|c|c|c|}
\hline \multirow{3}{*}{ Species } & \multicolumn{4}{|c|}{ Habitat } \\
\hline & \multicolumn{2}{|l|}{ Flat field } & \multicolumn{2}{|l|}{ Knoll } \\
\hline & $\begin{array}{c}\% \text { cover } \\
( \pm 95 \% \text { confidence } \\
\text { limits })\end{array}$ & $\begin{array}{c}\% f \\
(n=20)\end{array}$ & $\begin{array}{c}\% \text { cover } \\
( \pm 95 \% \text { confidence } \\
\text { limits })\end{array}$ & $\begin{array}{c}\% f \\
(n=22)\end{array}$ \\
\hline Agropyron cristatum & $18.9 \pm 8.1$ & 85 & 0 & 0 \\
\hline Agropyron spicatum & $0.1 \pm 0.2$ & 5 & $4.2 \pm 3.8$ & 59 \\
\hline Poa sandbergii & $13.8 \pm 6.5$ & 70 & $12.7 \pm 7.4$ & 73 \\
\hline Stipa comata & $12.2 \pm 8.3$ & 60 & $19.8 \pm 7.3$ & 95 \\
\hline Artemisia frigida & $3.9 \pm 4.0$ & 60 & $7.4 \pm 3.2$ & 68 \\
\hline Artemisia tridentata & $8.6 \pm 7.1$ & 40 & $8.8 \pm 9.1$ & 27 \\
\hline Chrysothamnus nauseosus & $1.5 \pm 2.2$ & 10 & $2.2 \pm 3.5$ & 23 \\
\hline
\end{tabular}


was made up on the knoll area by more use of shrubs. Rose (Rsa sp.), very sparse on the flat field, was abundant on the knoll and its consumption increased accordingly.

Grass utilized in the first sub-period was produced the previous fall. Although the grass was green, its palatability appeared reduced by frost damage resulting in the loss of turgor, and by soiling during the winter. Presumably, without fall regrowth grass consumption would be significant in sub-period 1 and reduced in sub-period 2. Spring growth of grass is not available until midMarch.

The data appear to negate the significance of competition between deer and cattle for springtime forage. Most of the grass used by deer is Sandberg bluegrass. This grass is in an advanced stage of maturity by mid-April when cattle are normally placed on the range. Furthermore, the leaves are short, usually less than $5 \mathrm{~cm}$ tall, and the flowering stalks are unpalatable. Consequently this species is not expected to contribute significantly to the cattle diets (McLean et al. 1964). In fact, Uresk and Richard (1976) found the preference for Sandberg bluegrass to be near zero for steers on similar range from early April to the end of May. The population of Sandberg bluegrass may increase with over-grazing by cattle. This long-term effect demonstrates the complexity involved in defining competition or interaction between two or more herbivore species.

\section{Seasonal Variation}

Changes in the dietary composition of plant types were most significant from sub-period 1 to sub-periods 2 and 3. During this time, the diet changes from predominantly shrubs to predominantly grass. The most important factor that affected selection changes from February to May was the increasing availability of new foliage. Generally, those species where the young growth was readily available were favored by deer. Grass provided the first acceptabel alternative to the two sage species following winter. Grass consumption dominated the deer's diet until sub-period 4 when forbs became available. It is also at this time that grass appeared to mature. Prehension of bluebunch wheatgrass by the deer appeared to become more difficult, as the fibrous leaves would slip between their lower incisors and upper dental pad rather than break.

The forbs used in sub-periods 1 and 2 and in part of sub-period 3 were green as a result of fall regrowth. Selection of the green forbs in preference to the aged plants suggests that forb consumption would have been less at this time if fall regrowth had not taken place. However, previous feeding observations of tame deer showed that they favored the mature, dried flowering stalks of false salsify (Tragopogon dubius) and mariposa lily (Calochortus macrocarpus) when alternate forage sources were limited (Willms et al. 1975). Perhaps the availability of green forbs in this study discouraged consumption of the less palatable material.

The period from mid-February to May represents basically a single diet with changes at the beginning and at the end. Although consumption of a species may increase or decrease during this period, the average is sufficiently modified by within-subperiod changes to negate large differences in the dietary composition of plant types among sub-periods.

\section{Animal Variation}

The variation of food selection among deer was estimated for theoretical and practical considerations. An understanding of diet variability among deer will assist in predicting range quality and uses. Range grazing capacity increases as food selection in a population becomes more diversified. Furthermore, to study the effects of other variables on food selection, it is important to remove as many extraneous factors as possible. This is done by stratifying animals into groups of similar selection responses.

The three deer used demonstrated two basic responses to forage selection. One male and the doe (deer 2 and 3) preferred grasses while the other male (deer 1) favored shrubs. These differences were apparent only in the knoll habitat and in the last three sub-periods (Table 2) after grass became more readily available. Variability among animals was lessened in the flat field habitat, possibly as a result of reduced availability of pasture sage. This species contributed to the greatest variation between the two groups of deer but represented only one-half as much cover in the flat field as in the knoll.

As a result of selection differences among animals, regressions of plant utilization with time (Table 3 ) were often improved by stratifying the data into two groups of deer. In several instances, the "significance" of the regression was lost since the degrees of freedom were reduced as well.

Stratification of the data by animal groups permits a more accurate description of the seasonal effects on food selection. Where the $R^{2}$ value for the equation which describes the seasonal diet is high, the implication is that the seasonal effect also is high. Conversely, a small $R^{2}$ value implies a small seasonal effect.

The number of animals used in this study is small; however, the variation found among them is typical of that reported by others. Rice and Church (1974) noted a pronounced sex effect on browse preference in black-tailed deer (Odocoileus hemionus columbianus). Tucker et al. (1977) noted a greater selection for Douglasfir by juvenile mule deer than by adult does while the latter showed a greater preference, than the juveniles, for snowbrush (Ceanothus velutinus). Although the nutritional value of selected forages is generally greater than the average nutritional value (Fonetnot and Blaser 1965; Coleman and Barth 1973), it is generally agreed that secondary effects are more important in determining forage selection (Marten 1969; Arnold and Hill 1972). Radwan (1972) and Tucker et al. (1976) report a correlation of Douglasfir preference with the presence of chlorogenic acid.

We believe variation in forage selection within a herbivore population ensures increased efficiency in the use of a diverse range resource and enhances the potential for population survival. Range grazing capacity is also increased. Variation in the forage selection of individual animals is estimated by the $R^{2}$ of the regression equation describing seasonal variation (Tables 2 and 3 ). Assuming the model selected to describe seasonal variation is the correct one, then the variation due to lack of fit is small and the $R^{2}$ accounts for all the variation contrib- 
uted by seasonal changes. The residual variation can then be attributed to selection differences within the animal. On the basis of this premise, we might conclude that the individual animal selects a highly variable diet.

Factors that effect forage selection are reviewed by Arnold and Hill (1972) and others. An additional factor observed during the trials relates to the animals' nervousness and to plant structure. On windy days, the animals appeared to prefer tall shrubs more than they normally would. It seemed that the increased movement of nearby trees and other plants produced enough noise to block auditory monitoring. The deer, therefore, became more dependent on sight to monitor their surroundings. Consequently, they became reluctant to put their heads near the ground to feed on grass where big sagebrush obscured their vision. When feeding on the shrubs, however, they were able to view their surroundings.

\section{Implications of Forage Selection and Crude Protein Payoff}

Although Sandberg bluegrass was used most often by the deer, its crude protein content is significantly less $(P<0.01)$ than in the other grass species. For example, the average protein levels for April and May were $11.7 \%$ for Sandberg bluegrass, $16.3 \%$ for needleandthread, $18.0 \%$ for fall-grazed crested wheatgrass, and $12.9 \%$ for cheatgrass (Bromus tectorum). Presumably, the absence of mature foliage among the green grass enhanced the preference for Sandberg bluegrass by deer. If this is true, the preference rating of other grass species would increase in relation to Sandberg bluegrass when the mature stalks were removed.

Where fall grazing has removed the mature stalks from plants of bluebunch wheatgrass and crested wheatgrass, the deer had easier access to the green foliage in the spring. Also our studies have shown the foliage had 2 to $3 \%$ more crude protein than in the regrowth where the mature stalks had not been removed. Green material from fall-grazed plants of bluebunch wheatgrass averaged $22.1 \%$ crude protein from midMarch to mid-April, while green material from plants ungrazed the previous fall averaged $20.0 \%$. Cor- responding values for crested wheatgrass were $23.6 \%$ and $20.8 \%$, respectively. A 2 or $3 \%$ increase is perhaps not important during March and April when protein content in forages is generally not limiting; however, the increased availability of forage caused by the removal of mature stalks can be significant in reducing the searching effort by deer and may increase total intake. This effect will, of course, vary with the species composition and alternate foods available on each range.

The nutritional importance of grass in early spring is not well known. Fierro (1977) found that deer fed pure diets of crested wheatgrass (29.7\% crude protein) in April showed neutral weight responses, thus suggesting its importance in arresting weight loss but not in reversing the negative energy balance established during winter. It is probable, however, that the spring-time availability of grass affects both mortality and fecundity of deer. Evidence to support this contention is by inferrence. Deer lose weight throughout the winter as a result of lowered nutrition of available forage (Moen 1973) and reduced ingestion of forage (Nordan et al. 1968). Also, the fetal demands for protein increases rapidly in April and May (Moen 1973). Protein restriction during this time has been associated with a poorly developed brain and a lack of passive immunity in humans and rats (Guthrie 1971). Although Moule (1962) and Eadie (1970) consider the effect of a low nutritional plane on the fetus of sheep to be small, the efficiency of food utilization in the offspring is reduced (Guthrie 1971) and post natal care will suffer (Reid 1960).

\section{Literature Cited}

Arnold, G. W., and J. L. Hill. 1972. Chemical factors affecting selection of food plants by ruminants. In: J. B. Harborne, ed., Phytochemical Ecology. Academic Press, N.Y. p. 71-101.

Coleman, S. W., and K. M. Barth. 1973. Quality of diets selected by grazing animals and its relation to quality of available forage and species composition of pastures. $\mathrm{J}$. Anim. Sci. 36:754-761.

Eadie, J. 1970. Sheep production and pastoral resources. In: A. Watson, Ed., Animal Populations in Relation to Food Resources. Blackwell, Oxford. p. 7-24.

Fierro, L. C. 1977. Influence of livestock grazing on the regrowth of crested wheatgrass for winter use by mule deer. Utah State Univ. M.S. Thesis. 67 p.
Fontenot, J. P., and R. E. Blaser. 1965. Symposium of factors influencing voluntary intake of herbage by ruminants: selection and intake of grazing animals. J. Anim. Sci. 24:1202-1208.

Goulden, C. H. 1952. Methods of Statistical Analysis. 2nd ed., John Wiley and Sons Inc., N.Y. 467 p.

Guthrie, H. A. 1971. Introductory Nutrition. 2nd ed., C. V. Mosly Co., St. Louis, Mo. $331 \mathrm{p}$.

Hickman, O. E. 1975. Seasonal trends in the nutritive content of important range forage species near Silver Lake, Oregon. U.S. Dep. Agr. Forest Serv., Pac. Northwest Forest and Range Exp. Sta. Res. Note PNW-187. Portland, Ore. 32 p.

Marten, G. C. 1969. Measurement and significance of forage palatability. Proc. Nat. Conf. on Forage Quality Eval. and Util., Pap. 7117. p. 1-54.

McLean, A. 1970. Plant communities of the Similkameen Valley, British Columbia and their relationships to soils. Ecol. Monogr. 49:403-423.

McLean, A., and W. D. Willms. 1977. Cattle diets and distribution on spring-fall, and summer ranges near Kamloops, British Columbia. Can. J. Anim. Sci. 57:81-92.

McLean, A., E. R. Smith, and W. L. Pringle. 1964. Handbook on grazing values of range plants of British Columbia. Can. Dep. Agr. Res. Sta., Kamloops. 41 p.

Moen, A. M. 1973. Wildlife Ecology. W. H. Freeman and Co., San Francisco. 458 p.

Moule, G. R. 1962. Field trials in retrospect: flushing. Proc. Aust. Soc. Anim. Prod. 4:195-200.

Nagy, J. G., and R. P. Tengerdy. 1968. Antibacterial action of essential oils of Artemisia as an ecological factor. II Antibacterial action of the volatile oils of Artemisia trodentata (Big sagebrush) on bacteria from the rumen of mule deer. Appl. Microbiol. 16:441-444.

Nordan, H. C., I. McT. Cowan, and A. J. Wood. 1968. Nutritional requirements and growth of black-tailed deer (Odocoileus hemionus columbianus) in captivity. In: M. A. Crawford, ed., Comparative Nutrition of Wild Animais. Symp. Zool. Soc., London, No. 21. p. 89-96.

Oh, H. K., M. B. Jones, and W. M. Longhurst. 1968. Comparison of rumen microbial inhibition resulting from various essential oils isolated from relatively unpalatable plant species. Appl. Microbiol. 16:39-44.

Payne, G. F. 1974. Cover-weight relationships. J. Range Manage. 27:403-404.

Radwan, M. A. 1972. Differences between Douglasfir genotypes in relation to browsing preference by black-tailed deer. Can. J. Forest Res. 2:250-255.

Regelin, W. L., R. M. Bartman, D. W. Reichert, and P. H. Neil. 1976. The influence of supplemental feed on food habits of tamed deer. U.S. Dep. Agr. Forest Serv. Res. Note RM-316. 4 p.

Reicher, D. W. 1972. Rearing and training deer for food habit studies. U.S. Dep. Agr. Forest Serv. Res. Note RM-208. 7 p.

Reid, R. L. 1960. Energy requirements of ewes in late pregnancy. In: E. Lewis, ed., Digestive Physiology and Nutrition of the Ruminant. Butterworth, London. p. 198204. 
Rice, P. R., and D. C. Church. 1974. Taste responses of deer to browse extracts, organic acids, and odors. J. Wildl. Manage. 38:830-836.

Tucker, R. E., W. Majak, P. D. Parkinson, and A. McLean. 1976. Palatability of Douglasfir foliage to mule deer in relation to chemical and spatial factors. J. Range Manage. 29:486-489.

Tucker, R. E., A. McLean, D. E. Waldern. 1977. Relative preference of mule deer for six shrubs at Kamloops, B.C. Can. J. Anim. Sci. 57:375-377.

Uresk, D. W., and W. H. Richard. 1976. Diets of steers on shrub-steppe rangeland in south central Washington. J. Range Manage. 29:464-466.

Wallmo, O. C., W. L. Regelin, and D. W. Reichert. 1972. Forage use by mule deer relative to logging in Colorado. J. Wildl. Manage. 36:1025-1033.
Willms, W. D., A. McLean, R. Ritcey, and D. J. Low. 1975. The diets of cattle and deer on rangeland. Canada Agr., Fall. p. 21-23. Willms, W. D., A. McLean, and R. Ritcey. 1976. Feeding habits of mule deer from fall to early spring on ranges near Kamloops, B.C. Can. J. Anim. Sci. 56:531-542. Wood, A. J., H. C. Nordan, and I. McT. Cowan. 1961. The care and management of wild ungulates for experimental purposes. J. Wild. Manage. 25:295-302. 